\title{
PROBLEMATIKA PENDIDIKAN AGAMA ISLAM DI SEKOLAH DAN PERGURUAN TINGGI UMUM
}

\author{
Akhmad Said \\ Dosen STAI Ma'had Aly Al-Hikam Malang
}

\begin{abstract}
Abstrak
The current moral decline of this nation, more or less was the impact of low achievement in moral education. To point out, there have been endless white collar criminals and corruptions, illegal logging, violence and anarchy, inter students' gang fight, and the castration of humanity. The failure of such moral education often be addresed as the failure of Religion Education particularly Islam, since Elementary until Higher Education/University.

The failure of education in Islamic Religion supposed to be related to a set of problems. Among these problems are curricula, teacher/educator, method and the dychotomic view between religious education and scientific one that it should be taught integrally. This writing will try to analize the mentioned problems and it possible solution.
\end{abstract}

Keywords; problems, Islam education, school/ higher education.

\section{Pendahuluan}

Pendidikan Agama sebagai penegak sendi-sendi moral kehidupan kini menghadapi problematika yang cukup serius baik dalam konsepsional maupun operasional, sehingga perlu segera adanya langkah-langkah kongkret untuk mengatasinya. Problematika tersebut paling tidak terlihat pada kenyataan yang terjadi pada masyarakat sebagai out put pendidikan saat ini yang banyak melakukan pelanggaran nilai-nilai moral yang mestinya harus ditegakkan dalam kehidupan sehari-hari. Indikasi pelanggaran ini antara lain bisa dilihat dari banyaknya kasus korupsi, penyalahgunaan wewenang, perselingkuhan, tawuran antar warga, bahkan tawuran antar pelajar.

Karena mereka merupakan out put pendidikan dengan berbagai tingkatannya, maka kondisi ini menurut hemat penulis merupakan rentetan panjang dari problematika pendidikan terutama pendidikan agama Islam yang diberikan di sekolah sampai dengan perguruan tinggi. 
Problematika tersebut antara lain terkait dengan masalah (1) kurikulum, (2) guru dan dosen, (3) metode pembelajaran, dan (4) adanya dikotomi antara pendidikan umum dan pendidikan agama.

Dalam hal kurikulum, muatan pendidikan agama Islam sangat terbatas hanya 2 (dua) kali tatap muka setiap minggu pada sekolah dan 3 (tiga) SKS pada perguruan tinggi umum. Dengan terbatasnya waktu untuk mata pelajaran/mata-kuliah pendidikan agama ini maka ranah materi hanya cukup untuk alokasi ranah kognitif tanpa menyentuh afektif dan psikomotornya,

Dalam hal guru dan dosen, sebagian dari mereka masih belum memenuhi standar kompetensi dan kualifikasi akademik, sehingga mereka harus dipacu untuk memenuhi standart kompetensi dan kualifikasi yang ditetapkan, misalnya guru minimal harus sarjana, dan dosen minimal harus magister seperti yang ditegaskan dalam Undang-Undang Sistem Pendidikan Nasional. Di samping itu permasalahan yang dialami para guru dan dosen dewasa ini mereka masih banyak yang gagap teknologi (gaptek), oleh karena itu agar mereka tidak tertinggal arus global, mereka juga harus dipacu untuk menguasai teknologi informasi.

Dalam hal metode pembelajaran, guru dan dosen Pendidikan Agama Islam dewasa ini masih banyak yang memberlakukan peserta didik sebagai obyek, sehingga mereka mengangap cukup dengan hanya menggunakan sistem pembelajaran satu arah, misalnya ceramah dan mendikte di hadapan siswa/mahasiswa. Padahal dalam pembelajaran dewasa ini sangat diperlukan dua arah komunikasi dengan memerankan peserta didik sebagai subyek. Di samping itu, metode keteladanan juga sangat penting diterapkan untuk pembelajaan dewasa ini.

Dalam hal dikotomi, ketika Pendidikan Agama Islam dan pendidikan umum dipisahkan yang terjadi adalah parsialisasi nilai-nilai moral dengan mata pelajaran/mata-kuliah yang ada. Padahal mestinya pengetahuan tidak boleh lepas dari nilai-nilai moral (value free), sehingga terjadi internalisasi nilai-nilai dengan mata pelajaran/mata-kuliah yang ada.

Problematika Pendidikan Agama Islam tersebut perlu segera mendapat solusi agar generasi yang akan datang sebagai subyek dan obyek pendidikan tidak terus menerus melakukan kesalahan yang berakibat pada terjadinya pelanggaran nilai-nilai moral oleh out put pendidikan seperti yang terjadi dewasa ini.

Tulisan sederhana ini akan mengetengahkan problematika Pendidikan Agama Islam, terutama yang terkait dengan empat hal tersebut di atas berikut alternatif pemecahannya. 


\section{A. Pentingnya Pendidikan Agama Islam}

Pesatnya perkembangan sains dan teknologi yang tidak disertai dengan nilai-nilai moral seperti yang terjadi di negara-negara maju dewasa ini cenderung melahirkan pola hidup manusia yang hedonis dengan mengabaikan nilai-nilai moral yang seharusnya dijadikan pegangan. Sejak munculnya para ilmuwan modern yang berkiprah di bidang filsafat dan sains, mereka telah mempermasalahkan apakah ilmu itu "bebas nilai" (Value Free) ataukah "terikat nilai" (Value Bond). Perbedaan pendapat dari dua madzhab ini hingga kini nampaknya belum berakhir. Madzhab yang berpegang pada "Value Free" secara bebas berbicara pada dataran wilayah ilmunya tanpa mengaitkan dengan nilai moral yang ada. Sementara itu, madzhab yang berpegang pada "Value Bond" berjuang keras untuk mengaitkan semua disiplin ilmu yang ada dengan nilai moral agar terjadi kesinambungan dan keseimbangan antara keduanya. Menurut madzhab kedua ini, ilmu dan moral harus berjalan seiring agar kehidupan manusia bisa terjamin keseimbangannya secara terpadu. Inilah sebenarnya yang merupakan hakikat pendidikan, seperti yang diketengahkan oleh Lodge (1947) bahwa pendidikan sebagai proses hidup dan sebagai kehidupan manusia cenderung berjalan serempak, tidak terpisah satu sama lainnya (life is education and education is life). Demikian pula Dewey (1966), menurutnya hakikat pendidikan adalah suatu kebutuhan hidup (a necessity of life), suatu fungsi sosial (a social function), sebagai bimbingan (as direction), sebagai sarana pertumbuhan (as growth) yang mempersiapkan serta membentuk disiplin hidup.

Pendapat dua pakar di bidang pendidikan tersebut memberi indikasi tentang hakikat, sifat, misi dan fungsi pendidikan sebagai pengemban nilai moral dan perilaku sehingga tercermin dan teraplikasikan dalam suatu kehidupan manusia secara nyata. Terkait dengan pentingnya nilai moral ini Undang-Undang Nomor 20 Tahun 2003 tentang Sistem Pendidikan Nasional pada Bab I Pasal 1 menyebutkan:

"Pendidikan adalah usaha sadar dan terencana untuk mewujudkan suasana belajar dan proses pembelajaran agar peserta didik secara aktif mengembangkan potensi dirinya untuk memiliki kekuatan spiritual keagamaan, pengendalian diri, kepribadian, kecerdasan, akhlak mulia, serta keterampilan yang diperlukan dirinya, masyarakat, bangsa dan Negara".

Dari konsideran di atas nampak jelas bahwa kekuatan spiritual keagamaan yang berisi nilai-nilai moral merupakan perioritas dalam sistem pendidikan kita, sehingga ke depan pendidikan nasional diharapkan bisa menghasilkan out put manusia yang beriman dan bertakwa serta berakhlak yang mulia/bermoral. Hal ini sesuai dengan fungsi dan tujuan pendidikan 
yang tercantum pada Bab II Pasal 3 Undang-Undang Sistem Pendidikan Nasional sebagai berikut :

"Pendidikan nasional berfungsi mengembangkan kemampuan dan membentuk watak serta peradaban bangsa yang bermartabat dalam rangka mencerdaskan kehidupan bangsa, bertujuan untuk berkembangnya potensi peserta didik agar menjadi manusia yang beriman dan bertakwa kepada Tuhan Yang Maha Esa, berakhlak mulia, sehat, berilmu, cakap, kreatif, mandiri, dan menjadi warga negara yang demokratis serta bertanggung jawab".

Dari uraian di atas jelaslah bahwa pendidikan moral merupakan sesuatu yang hakiki bahkan menduduki tempat sentral dalam pendidikan. Hal ini menunjukkan sekaligus mengingatkan kepada lembaga-lembaga pendidikan di negeri tercinta ini agar menengok kembali hakikat, sifat dan fungsi pendidikan secara menyeluruh baik dari aspek kognitif, afektif maupun psikomotornya. Dengan demikian lembaga pendidikan tidak hanya sebagai tempat untuk melahirkan manusia yang smart dalam olah pikir atau bahkan hanya memproduk ijasah seperti yang disinyalir oleh sebagian orang, melainkan sebagai sarana membentuk manusia yang memiliki kualitas olah pikir dan kepribadian secara utuh. Dengan kata lain pendidikan pada hakikatnya akan membentuk manusia yang pintar dan bermoral.

Dalam bahasa agama, moral identik dengan akhlak yang pada hakikatnya merupakan inti dari misi Islam. Dalam ajaran Islam dikenal sebuah riwayat hadis yang artinya : "Aku (Muhammad) diutus hanyalah untuk menyempurnakan akhlak yang mulia" (HR. Tirmidzi). Menurut hadis tersebut akhlak/moral merupakan inti ajaran agama Islam, sehingga orang yang tidak berakhlak pada hakikatnya dia bukanlah orang Islam, sekalipun secara formal dia tercatat sebagai pemeluk agama Islam. Jika demikian berarti Pendidikan Agama Islam memberi peran yang sangat signifikan dalam penanaman nilainilai moral. Peran Pendidikan Agama Islam ini semakin nampak jelas ketika dihadapkan pada fenomena yang terjadi pada kehidupan masyarakat dewasa ini. Kebejatan moral yang sudah sampai pada tingkat membahayakan; tawuran antar warga, pertikaian antar etnis dan golongan, bahkan antar pelajar dan mahasiswa, perilaku para elit politik yang cenderung mementingkan ambisi pribadi dan golongan masing-masing, serta praktek korupsi yang telah menyatu dalam perilaku para pejabat sehingga menambah beban ekonomi rakyat. Demikian pula kekejaman dan keberingasan manyarakat bawah yang tidak lagi bisa ditolerir; mereka rela membunuh orang lain hanya disebabkan permasalahan yang sangat sepele. Di kalangan para remaja juga sudah berlebihan; mereka yang seharusnya menjadi harapan dalam menyongsong masa depan bangsa malah tercebur 
dalam kasus narkoba yang mematikan dan pergaulan bebas (free sex) yang membahayakan. ${ }^{1}$ Krisis ini terjadi karena mereka meninggalkan agama dan mencampakkan nilai-nilai moral yang ada di dalamnya. Untuk mengatasi hal itu Pendidikan Agama Islam sangat diperlukan, agar masyarakat yang nota bene merupakan out put dari pendidikan ini lebih mengedepankan moral dalam semua aktivitas kehidupannya. Oleh karena itu peran Pendidikan Agama Islam menjadi sangat penting untuk memecahkan permasalahan bangsa dan masyarakat yang sangat krusial ini.

Selanjutnya, agar Pendidikan Agama Islam bisa berhasil sesuai dengan yang diharapkan, maka problematika yang banyak dihadapi baik yang terkait dengan konsepsional maupun operasional harus segera diatasi, terutama yang terkait dengan masalah kurikulum, guru dan dosen, metode, dan dikotomi yang terjadi antara pendidikan agama dan pendidikan umum.

\section{B. Problematika Pendidikan Agama Islam}

\section{Problem Kurikulum}

Dalam dunia pendidikan kurikulum merupakan suatu hal yang sangat esensial untuk membawa suatu proses pendidikan sampai pada capaian yang diinginkan. Dalam bahasa Arab kurikulum identik dengan al-manhaj yang difahami sebagai seperangkat rencana dan media untuk mengantarkan sebuah lembaga pendidikan dalam mencapai suatu tujuan pendidikan yang dicanangkan. ${ }^{2}$ Dalam Undang Undang Nomor 20 Tahun 2003 tentang Sistem Pendidikan Nasional Bab I, Pasal 1, ayat 19 disebutkan bahwa "Kurikulum adalah seperangkat rencana dan pengaturan mengenai tujuan, isi, dan bahan pelajaran serta cara yang digunakan sebagai pedoman penyelenggaraan kegiatan pembelajaran untuk mencapai tujuan pendidikan tertentu".

Dari pengertian di atas dapat dipahami bahwa kurikulum dalam sebuah lembaga pendidikan memuat komponen tujuan pendidikan, isi dan bahan pelajaran, serta cara pembelajaran baik yang terkait dengan strategi maupun evaluasi pembelajarannya. Oleh karena itu berbicara mengenai kurikulum pendidikan sebenarnya mencakup semua komponen yang digunakan untuk mencapai tujuan pendidikan. Namun demikian dalam tulisan yang sderhana ini penulis hanya membatasi permasalahan kurikulum

1

Laporan hasil penelitian skripsi di Malang menunjukkan bahwa sejumlah 85 \% para mahasiswi di salah satu asrama mengaku sudah melakukan aborsi akibat sex bebas (Eva Nurdiana : 2006).

Al-Khauly, Muhamad Ali, Qamus al-Tarbiyah: Injlizy 'Araby, Beirut Libanon ; Dar al'Illm li al Malayin, 1981 
pada bahan pembelajaran dan keterbatasan waktu yang tersedia baik di sekolah maupun di perguruan tinggi umum.

Sebagaimana yang pernah diketengahkan oleh Menteri Agma RI (Maftuh Basyuni) bahwa Pendidikan Agama Islam dewasa ini lebih cenderung mengedepankan aspek kognisi dari pada aspek afeksi dan psikomotorik ${ }^{3}$; Artinya bahwa Pendidikan Agama Islam lebih terfokus pada pemikiran dan belum banyak menyentuh pada aspek kemauan dan tekat untuk mengamalkan ajaran yang terkandung di dalamnya. Peserta didik hanya dipacu untuk menghafal muatan bahan pembelajaran yang ada sehingga bisa mendapat nilai raport yang bagus. Akhirnya terjadi kesenjangan antara pengetahuan dan pengamalan, sehingga Pendidikan Agama Islam tidak mampu membentuk peserta didik sebagai pribadi-pribadi yang beragama. Dalam nilai raport/kartu hasil studi (KHS) Pendidikan Agama Islam tercatat mendapat nilai 100/A+ tetapi yang bersangkutan tidak shalat, bahkan selalu mengganggu orang lain yang sedang shalat. Atau dia melakukan shalat hanya sekedar ritual karena diabsen oleh guru/dosennya, sedangkan dalam kehidupan sehari-hari sama sekali mengabaikan nilai-nilai moral keagamaan.

Terkait dengan permasalahan ini biasanya para guru/dosen dan lembaga pendidikan selalu mengkambing hitamkan jam pelajaran yang sangat minim dan tidak imbang. Sebab jam pelajaran di sekolah hanya dialokasikan 2 jam tatap muka setiap minggu dan di perguruan tinggi umum hanya diberi bobot 3 SKS (Kep. Dirjen Dikti Nomor : 43/DIKTI/Kep.2006)

Permasalahan muatan kurikulum Pendidikan Agama Islam ini sebenarnya bisa disiasati oleh masing-masing lembaga pendidikan baik sekolah maupun perguruan tinggi umum dengan mengalokasikan waktu tambahan untuk kegiatan ekstra kurikuler keagamaan dengan menekankan pada aspek afektif dan psikomotor, sehingga para peserta didik bisa menginternalisasikan Pendidikan Agama Islam dalam perilaku mereka seharihari. Hanya saja biasanya lembaga pendidikan berat melakukan kegiatan ektra tersebut karena terbentur pendanaan.

\section{Problem Guru/Dosen}

Dalam bahasa Arab guru/dosen biasa disebut dengan Ustadz. Sementara itu dalam terminologi yang lain Ustadz juga berarti Profesor. Dari terminologi ini terkandung makna bahwa guru/dosen dituntut untuk melaksanakan tugas secara profesional; yakni punya dedikasi dan komitmen 
yang tinggi terhadap mutu pendidikan, dan terus menerus berinovasi dalam melaksanakan tugas-tugasnya.

Terkait dengan masalah ini dalam Undang-Undang Nomor 14 Tahun 2005 tentang Guru dan Dosen Pasal 1 menegaskan :

1. Guru adalah pendidik profesional dengan tugas utama mengajar, mendidik, membimbing, mengarahkan, melatih, menilai, dan mengevaluasi peserta didik pada pendidikan anak usia dini jalur pendidikan formal, pendidikan dasar, dan pendidikan menengah.

2. Dosen adalah pendidik profesional dan ilmuan dengan tugas utama mentransformasikan, mengembangkan, dan menyebarluaskan ilmu pengetahuan, teknologi, dan seni melalui pendidikan, penelitian, dan pengabdian kepada masyarakat.

Dari konsideran tersebut dapat dipahami bahwa dalam melaksanakan tugas-tugas guru dan dosen harus profesional. Mereka harus memiliki dedikasi dan komitmen yang tinggi untuk meningkatkan mutu pendidikan dengan berbagai cara, memiliki kompetensi dan kualifikasi akademik yang diperlukan sesuai dengan bidang tugas, serta memiliki kualifikasi akademik dan latar belakang pendidikan yang relevan.

Dalam hal peningkatan mutu pendidikan serta kompetensi guru/dosen harus menguasai ICT (Information and Communication Technology). Sebab di era global ini teknologi informasi begitu maju pesat sehingga semua informasi bisa diakses dengan mudah oleh siapa pun termasuk para siswa/mahasiswa. Dalam kaitan ini Maftuh Basyuni (Menteri Agama RI) menegaskan .. "Dalam era perkembangan sains dan teknologi, umat Islam harus memanfaatkan teknologi agar dapat menghadapi dan melakukan proses transformasi, ${ }^{4}$. Oleh karena itu guru/dosen yang tidak menguasai ICT akan sulit bisa meningkatkan mutu dan kompetensi di bidang masing-masing.

Selanjutnya dalam hal kualifikasi akademik guru dipersyaratkan minimal berpendidikan Program Sarjana/Diploma empat (UU Nomor 14 Tahun 2005, Pasal: 9), dan dosen minimal berpendidikan Program Magister/S-2 (Pasal: 46).

Terkait dengan masalah tersebut guru/dosen Pendidikan Agama Islam (PAI) masih banyak yang belum memenuhi syarat. Dalam hal penguasaan ICT mereka masih banyak yang gagap teknologi, sehingga perlu adanya pelatihan-pelatihan secara intensif agar mereka melek teknologi, khususnya teknologi informasi yang sangat membantu dalam melaksanakan tugas-tugas mereka. Demikian pula dalam hal kualifikasi akademik,

${ }^{4}$ www.depag.go.id/12 Pebruari 2009 
guru/dosen Pendidikan Agama Islam masih banyak yang belum memenuhi syarat minimal; banyak di antara guru PAI yang belum sarjana, dan banyak di antara dosen PAI yang belum Magister, sehingga perlu memberikan motivasi kepada mereka untuk memacu diri memenuhi syarat minimal kualifikasi akademik tersebut dengan mengikuti program beasiswa yang disediakan oleh pemerintah.

\section{Problem Metode}

Dalam proses pendidikan metode merupakan komponen yang sangat penting untuk mencapai tujuan yang diharapkan. Oleh karena itu Pendidikan Agama Islam harus dilaksanakan dengan metode yang tepat sesuai dengan kebutuhan dan perkembangan siswa/mahasiswa. Terkait dengan masalah tersebut Direktorat Perguruan Tingi Islam Departemen Agama RI memberi penegasan tentang metode pembelajaran PAl yang dirancang berbasis kompetensi sebagai berikut ${ }^{5}$ :

a. Kuliah yang dilengkapi response, tugas baca, dan telaah kasus.

b. Diskusi kelompok dengan arahan dan tuntunan dosen.

c. Studi kasus.

d. Seminar kecil.

e. Kuliah kerja maupun pemagangan.

f. Observasi lapangan

Dari rambu-rambu di atas jelaslah bahwa metode pendekatan yang digunakan dalam pembelajaran Pendidikan Agama Islam adalah dengan menempatkan peserta didik sebagai subyek yang aktif dan bukan hanya sebagai obyek. Mahasiswa diajak menelaah kasus yang sedang terjadi melalui diskusi, seminar, observasi ke lapangan, atau dengan praktek ibadah, sehingga ranah afektif dan psikomotor akan lebih dominan di samping ranah kognitif. Cara seperti ini akan menumbuhkan motivasi kepada mahasiswa agar bisa mengembangkan kepribadiannya dan menganggap mata-kuliah agama sebagai kebutuhan dalam kehidupannya.

Selain metode-metode tersebut dalam pembelajaran Pendidikan Agama Islam metode keteladanan juga harus dikedepankan. Dalam hal ini guru/dosen Pendidikan Agama Islam adalah figur sentral yang dijadikan teladan. Di lingkungan sekolah/perguruan tinggi, para guru/dosen agama harus bisa memberikan contoh yang baik kepada mahasiswa sesuai dengan

5 Direktorat Perguruan Tinggi Agama Islam Departemen Agama RI., Materi Interaksional Pendidikan Agama Islam di Perguruan Tingi Umum. Jakarta : Dipertais, 2004 
norma-norma ajaran Islam. Dalam pepatah dikatakan :"Guru kencing berdiri murid kencing berlari". Seorang siswa/mahasiswa sulit diharapkan mengikuti perintah dosen/gurunya agar berlaku jujur dan disiplin sementara guru/dosennya sendiri sering datang terlambat dalam mengajar. Demikian pula para siswa/mahasiswa akan sulit dilarang merokok sementara guru/dosennya sendiri merokok di hadapan mereka.

Dari sini jelaslah bahwa teladan yang diberikan oleh para pendidik akan berdampak langsung terhadap peserta didik. Oleh karena itu para guru/dosen agama tidak hanya dituntut pandai dalam menyampaikan materi perkuliahan saja, akan tetapi yang lebih penting adalah bagaimana mereka memberikan contoh teladan dalam kehidupan sehari-hari. Dalam agama Islam orang yang hanya pandai mengatakan tanpa diikuti dengan perbuatan ia diancam dan dibenci oleh Allah. Firman-Nya dalam surat al-Shaf ayat 3 yang artinya :"Amat besar kebencian Allah jika kalian mengatakan sesuatu yang tidak kalian kerjakan (QS. 61: 3).

Demikianlah secara garis besar metode pembelajaran mata-kuliah Pendidikan Agama Islam yang seharusnya diterapkan oleh para guru dan dosen di sekolah dan perguruan tinggi. Namun yang terjadi di lapangan ditengarai adanya penerapan metode pembelajaran Pendidikan Agama Islam yang masih terbatas pada cara-cara tradisional, seperti ceramah, mendekte, dan menghafal. Metode pembelajaran seperti ini kurang bisa mendorong penjiwaan terhadap nilai-nilai keagamaan. Bahkan Muhaimin mensinyalir adanya 3 (tiga) kelemahan metode pembelajaran PAI dewasa ini, yaitu : (1) kurang bisa mengubah pengetahuan agama yang kognitif menjadi makna dan nilai yang perlu diinternalisasikan dalam diri peserta didik; (2) kurang bisa berjalan bersama dan bekerja sama dengan program-program pendidikan non agama; (3) kurang mempunyai relevansi terhadap perubahan sosial yang terjadi di masyarakat, sehingga peserta didik kurang menghayati nilai-nilai agama sebagai nilai yang hidup dalam keseharian. ${ }^{6}$

Problem metode Pendidikan Agama Islam ini bisa diatasi dengan (1) lebih memberi peluang seoptimal mungkin kepada peserta didik untuk berperan dalam proses pembelajaran, (2) lebih menekankan pada pembentukan sikap dan perilaku keagamaan, (3) lebih mengedepankan keteladanan oleh guru/dosen.

6 Muhaimin, Pengembangan Kurikulum Pendidikan Agama Islam, Jakarta : Raja Grafindo Persada, 2009 


\section{Problem Dikotomi}

Islam adalah agama yang sempurna mencakup keseluruhan aspek kehidupan, sehingga Pendidikan Agama Islam mestinya meliputi semua bidang keilmuan tanpa membedakan antara ilmu dunia dan ilmu akhirat atau ilmu umum dan ilmu agama. Hal ini paling tidak terbukti dengan turunya ayat pertama yang berbunyi إقرأ yang berarti "bacalah". Perintah membaca ini disampaikan di saat belum ada ayat al-Qur'an yang lain, sehingga konotasi perintah itu bisa diartikan untuk membaca ayat-ayat kauniyah yang tersebar di seluruh alam semesta ini. Jika demikian berarti pengembangan ilmu pengetahuan tidak perlu dibedakan antara ilmu agama dan ilmu umum, bahkan keduanya bisa saling melengkapi dan saling mendukung. Inilah yang terjadi pada periode Islam klasik, bahkan pada masa kejayaan Islam semua ilmu pengetahuan dikuasai oleh umat Islam, mulai dari ilmu fiqih sampai dengan ilmu fisika serta ilmu-ilmu yang lain. Bahkan buku-buku karangan mereka dipelajari dan dikembangkan di Eropa pada Periode Pencerahan yang akhirnya ilmu pengetahuan bisa berkembang pesat di Barat seperti yang kita saksikan sekarang ini.

Paradigma dikotomis ini sebenarnya mulai terjadi pasca Mu'tazilah meninggalkan pemerintahan Islam. Pada saat itu umat Islam mulai kurang menghargai ilmu pengetahuan yang berkonotasi pada ayat-ayat kauniyah karena hal itu dianggap kurang ada relevansinya dengan akhirat. Mereka senang hanya mengembangkan ilmu-ilmu yang berkaitan langsung dengan ayat-ayat Qur'aniyah dengan memarjinalkan ilmu-ilmu yang berkonotasi pada ayat-ayat kauniyah. Padahal keduanya mesti harus berjalan seimbang dan saling mendukung. Kondisi ini diperparah lagi ketika umat Islam dijajah oleh bangsa Barat termasuk Indonesia yang lebih dari 300 tahun dalam cengkeraman pemerintah Belanda. Penetrasi Belanda ke bumi Nusantara ini mengambil bagian yang signifikan dalam mempertegas dikotomisasi Pendidikan Agama Islam. Sebab para ulama sangat membenci terhadap semua yang dibawa penjajah termasuk ilmu pengetahuan yang kemudian dikonotasikan dengan ilmu umum, sehingga semakin tegas mereka membedakan antara imu agama dan ilmu umum.

Dikotomi ilmu agama dan ilmu umum ini masih kita rasakan sampai sekarang, sehingga dalam urusan pendidikan di Indonesia di samping menginduk pada Departemen Pendidikan Nasional yang mengurusi pendidikan umum juga Departemen Agama yang mengurusi pendidikan agama. Pemisahan antara ilmu agama dan ilmu umum ini berimplikasi terhadap pengembangan Pendidikan Agama Islam yang hanya terfokus pada 
orientasi keakhiratan, sedangkan masalah dunia dianggap tidak penting, karena mereka salah dalam memahami hadis :

$$
\text { الدنيا سجن المؤمن وجنة الكافر (سنن الترمذي - (ج } 4 \text { / ص 562) }
$$

("Dunia adalah penjara bagi mukmin, dan surga bagi kafir" (HR Tirmidzi), sehingga mereka apatis terhadap urusan dunia dan ilmu-ilmu yang terkait dengan keduniaan. Padahal hadis di atas sebenarnya mengandung makna tentang kenikmatan dunia yang hanya sangat terbatas seperti halnya kesengsaraan dalam penjara jika dibandingkan dengan kenikmatan akhirat yang tak terbatas.

Demikian pengaruh negatif dari adanya dikotomi Pendidikan Agama Islam ini sehingga perlu ada upaya untuk memulihkannya sebagaimana yang terjadi pada Periode Klasik, di mana Pendidikan Agama Islam mencakup keseluruhan bidang keilmuan tanpa adanya pemisahan dan terminologi yang berbeda antara ilmu agama dan ilmu umum. Di samping itu, upaya untuk memulihkan Pendidikan Agama Islam ini juga ditempuh dengan merubah status IAIN dan STAIN menjadi UIN sebagaimana yang sudah terjadi pada beberapa IAIN dan STAIN akhir-akhir ini. Atau upaya yang lebih ekstrim lagi dalam menghapus dikotomisasi Pendidikan Agama Islam ini adalah dengan mengembalikan Pendidikan ke satu atap; yaitu menginduk ke Departemen Pendidikan Nasional, sehingga Departemen Agama tidak perlu lagi mengurusi masalah pendidikan. Wallahu a'lam bisshowab

\section{Penutup}

Dari uraian di atas dapat disimpulkan bahwa Pendidikan Agama Islam dewasa ini banyak mengalami problematika dengan indikasi banyaknya penyimpangan perilaku masyarakat selaku out put dari berbagai lembaga pendidikan di negeri ini. Problematika tersebut antara lain:

1. Problem kurikulum yang muatannya lebih terfokus pada aspek kognitif dengan alokasi waktu yang sangat terbatas; yaitu 2 kali tatap muka setiap minggu di Sekolah dan 3 SKS di Perguruan Tinggi Umum. Solusi yang harus ditempuh adalah dengan menambah jam ekstrakurikuler dengan menekankan pada aspek afektif dan psikomotor.

2. Problem guru/dosen yang masih banyak belum memiliki kompetensi dan kualifikasi akademik serta belum menguasai ICT. Solusi yang harus ditempuh adalah dengan meningkatkan kualifikasi akademik para guru dan dosen serta memberi pelatihan ICT kepada mereka.

3. Problem metode yang masih banyak terfokus pada pemberlakuan terhadap peserta didik sebagai obyek dengan mengabaikan aspek 
keteladanan. Solusi yang harus ditempuh adalah dengan memberlakukan para siswa/mahasiswa sebagai subyek, serta banyak memberi contoh kepada mereka dalam perilaku sehari-hari

4. Problem dikotomi yang memilah antara Pendidikan Agama dengan pendidikan umum. Solusi yang harus ditempuh adalah dengan menyatukan terminologi ilmu agama dan ilmu umum serta memasukkan nilai-nilai keagamaan pada semua pelajaran/mata-kuliah, merubah IAIN/STAIN menjadi UIN, dan menyatukan urusan pendidikan ke Departemen Pendidikan Nasional, sehingga Departemen Agama dibebaskan dari urusan pendidikan.

\section{Daftar Rujukan}

Al-Qur'anul Karim

al-Khauly, Muhamad Ali, Qamus al-Tarbiyah: Injlizy 'Araby, Beirut - Libanon ; Dar al'Ilm li al Malayin, 1981.

Al-Tirmidzi. t.th. Abu Isa Muhammad ibn Isa. Sunan al-Tirmidzi ,Beirut : Dar al-Kutub al-Ilmiyyah.

Dewey, John.. Democracy and Education. New York : The Free Press, 1966

Direktorat Jenderal Pendidikan Tinggi, Keputusan Nomor : 43/DIKTI/Kep.2006, Jakarta : Dikti, 2006.

Direktorat Perguruan Tinggi Agama Islam Departemen Agama RI., Materi Interaksional Pendidikan Agama Islam di Perguruan Tingi Umum. Jakarta : Dipertais, 2004.

Eva Nurdiana,. Aborsi dalam Tinjauan Hukum Islam. Skripsi. Tidak diterbitkan. Malang : Fakultas Hukum Universitas Merdeka Malang, 2006.

Lodge, Rupert C., Philosophy of Education. New York : Harer \& Brother, 1947

Muhaimin, Pengembangan Kurikulum Pendidikan Agama Islam, Jakarta : Raja Grafindo Persada, 2009.

Pemerintah RI., Undang-undang Nomor 20 Tahun 2003 tentang Sistem Pendidikan Nasional. Jakarta : Depdiknas, 2003

Pemerintah RI., Undang-Undang Nomor 14 Tahun 2005 tentang Guru dan Dosen, Jakarta : depdiknas, 2005.

Tempo, 24 Nopember 2004, "Pendidikan Agama Belum Capai tujuan"www.depag.go.id/ diakses 12 Pebruari 2009. 